\title{
GPR56 Is Essential for Testis Development and Male Fertility in Mice
}

\author{
Guangchun Chen ${ }^{1,4}$, Liquan Yang ${ }^{1}$, Shahinoor Begum ${ }^{3}$, and Lei $\mathbf{X u}^{1,2, \#}$ \\ ${ }^{1}$ Department of Biomedical Genetics, University of Rochester Medical Center, Rochester, NY \\ 14642 \\ 2 Department of Dermatology, University of Rochester Medical Center, Rochester, NY 14642 \\ ${ }^{3}$ Howard Hughes Medical Institute and Koch Institute for Integrative Cancer Research, \\ Massachusetts Institute of Technology, Cambridge, MA 02139
}

\begin{abstract}
Testis development is essential for male fertility and continuation of the mammalian species. Essential structural components of testes are seminiferous tubules, which are lined by Sertoli cells and provide nutrients and physical protection for the maturation of sperm. Seminiferous tubule formation is initiated in embryos as testis cords and relies on their remodeling for maturation during development. Recently, 3-D image analyses showed that testis cords in different parts of embryonic gonads undergo distinct remodeling processes. How this asymmetric remodeling is regulated has not been investigated. We report here that the absence of an adhesion G proteincoupled receptor, GPR56, leads to partial disruption of seminiferous tubules and reduced fertility in male mice. The defects appear to originate asymmetrically in embryonic gonads, but subsequent to the initial establishment of testis cords, suggesting that GPR56 might act to establish a spatial and/or temporal cue for asymmetric cord remodeling during male gonad development.
\end{abstract}

\section{Keywords}

GPR56; testis; seminiferous tubules; fertility; polarity

\section{Introduction}

Testis is the major organ for male sexual development and fertility (Brennan and Capel, 2004; Wilhelm et al., 2007). It secretes hormones to promote male-specific traits and produces sperm for reproduction. The key structural components in testes are seminiferous tubules, which provide physical barriers and nutrient supplies for the survival and maturation of sperm. Seminiferous tubules are formed from epithelial-like Sertoli cells, along with associated myofibroblast-like peritubular myoid (PM) cells at the periphery. During testis development, Sertoli cells and PM cells secrete specific extracellular matrix proteins and assemble a layer of basement membrane (BM) in between (Tung et al., 1984a) to separate the seminiferous tubules from the interstitial space, where Leydig cells, endothelial cells and other unidentified mesenchymal cells reside. In adults, proper function of Sertoli cells and interstitial cells is maintained by circulating hormones, such as

\footnotetext{
\#Correspondence to: Lei Xu, Department of Biomedical Genetics, Department of Dermatology, 601 Elmwood Ave. Box 633, University of Rochester Medical Center, Rochester, NY 14642. lei_xu@ urmc.rochester.edu; telephone: 585-273-1302; fax: 585-273-1450.

${ }^{4}$ Current address: Department of Microbiology and Immunology, University of Rochester Medical Center, Rochester, NY 14642
} 
testosterone and the pituitary gonadotrophins including luteinising hormone (LH) and follicle-stimulating hormone (FSH) (O’Shaughnessy et al., 2009).

Mouse testis is differentiated from the genital ridge, a thickening of coelomic epithelium, during embryogenesis (Brennan and Capel, 2004; Wilhelm et al., 2007). At E11.5, the expression of the male-specific gene, Sry, induces the expression of SOX9, which leads to differentiation and aggregation of Sertoli cells around primordial germ cells and subsequent formation of testis cords. These primitive testis cords later elongate and remodel into seminiferous tubules in adults. Meanwhile, interstitial cells are believed to migrate from the adjacent mesonephros (Martineau et al., 1997) and play active roles in facilitating testis development (Buehr et al., 1993; Tilmann and Capel, 1999).

Although the molecular events that govern the initial establishment of testis cords have been well characterized, the control of their expansion and elongation is less understood.

Recently, 3D imaging analyses revealed significant remodeling of testis cords during embryogenesis (Combes et al., 2009). The remodeling appeared to occur differently across different parts of the gonad: the testis cords on the coelomic side organized into looped tubular structures, but those on the mesonephric side coalesced into a flattened network (Combes et al., 2009). This network is also called rete primordium because it is thought to develop into rete testes in adults. Molecular pathways that specify the differential remodeling of rete primordium and coelomic testis cords are not known.

GPR56 is a member of the adhesion G protein-coupled receptors (GPCRs), a family of newly identified adhesion receptors thought to regulate cell adhesion through $\mathrm{G}$ proteincoupled signaling (Yona et al., 2008). The adhesion GPCRs are highly conserved throughout evolution (Whittaker et al., 2006; Yona et al., 2008) and over 30 members are present in mammals, but their functions are just beginning to be unraveled. GPR56 plays important roles in human development and diseases. Mutations in the human GPR56 gene were associated with bilateral frontoperietal polymicrogyri (BFPP) (Piao et al., 2004), a type of mental retardation in humans, and expression of GPR56 inhibited melanoma progression in xenograft models (Xu et al., 2006). Consistent with its roles in brain development and cell adhesion, Gpr56 knockout mice were reported to exhibit defects of basement membrane assembly in both cerebrum and cerebellum (Li et al., 2008; Koirala et al., 2009).

We present evidence here that GPR56 also plays essential roles in mouse testis development. It is expressed in Sertoli cells, and in its absence, the seminiferous tubules were not properly formed, resulting in reduced male fertility. The defects in $\mathrm{Gpr} 56^{-1-}$ seminiferous tubules appear to originate during embryogenesis, after the initial establishment of testis cords, indicating that GPR56 may be involved in testis cord remodeling. Interestingly, disruptions of testis cords were only observed on the mesonephric side of $\mathrm{Fpr} 56^{-/-}$gonads, providing the first genetic evidence for the asymmetric formation of testis cords in mouse gonads and regulation of this process by a novel adhesion receptor, GPR56.

\section{Results}

\section{Gpr56 mRNA and its encoded protein are expressed in Sertoli cells in mouse gonads}

We examined the expression patterns of Gpr56 mRNA and its encoded protein in mouse male gonads by whole mount in situ hybridization and immunostaining analyses. An RNA probe complementary to exons 2 and 3 of mouse Gpr56, which were replaced by a neomycin-resistant cassette in $\mathrm{Gpr} 56^{-1-}$ mice, was synthesized and incubated with the whole genital ridges of E16.5 $\mathrm{Gpr} 56^{+/+}$or $\mathrm{Gpr} 56^{-/-}$embryos. It specifically labeled cordlike structures in E16.5 wild-type embryos (Figure 1A), suggesting that Gpr56 is expressed 
in one or several cell types in testis cords, including PM cells, Sertoli cells, and germ cells, but not the interstitial cells (e.g., Leydig cells and endothelial cells). Consistently, coimmunostaining using antibodies against the C-terminus of GPR56 (Xu et al., 2006) and the Sertoli cell marker, Anti-Mullerian Hormone (AMH), showed localization of GPR56 in Sertoli cells in embryonic gonads (Figure 1B).

Recently, microarray analyses have been performed to identify genes that are differentially expressed in testicular cell types (Shima et al., 2004). The results revealed high expression levels of Gpr56 mRNA in Sertoli cells and spermatogonia cells, consistent with our findings above, but low levels of Gpr56 in PM cells and mature spermatocytes (http://mrg.genetics.washington.edu, Supplementary Figure 1). Since Sertoli cells are essential for testis development but germ cells are not (McLaren, 1991), we performed western blot analyses to confirm the expression of GPR56 in Sertoli cells. Primary Sertoli cells were prepared from $\mathrm{Gpr}_{56^{+/-}}$or $\mathrm{Gpr} 56^{-/-}$testes of 4-week old mice (see Materials and Methods). Lysates were subjected to western blot analyses using the anti-GPR56 antibody and the anti-SOX9 antibody. SOX9 was detected in both lysates, confirming the origin of Sertoli cells in these preparations (Figure 1C). However, its level appeared to be slightly decreased in $\mathrm{Gpr}^{-6^{-1-}}$ lysates relative to $\mathrm{Gpr} 56^{+/-}$lysates, suggesting that GPR56 might regulate the expression of SOX9 in Sertoli cells (Figure 1C). In addition, a band of $\sim 25 \mathrm{kDa}$ corresponding to the C-terminal fragment of GPR56 was specifically detected by the anti-GPR56 antibody in $\mathrm{Gpr}_{56^{+/-}}$lysates but not in $\mathrm{Fpr}_{5} 6^{-/-}$lysates (Figure 1C), indicating that GPR56 is indeed expressed in Sertoli cells. Our results, however, could not exclude the possibility of GPR56 expression in PM cells, which might also contribute to seminiferous tubule formation in mice.

\section{Fertility is impaired in Gpr56-/- male mice}

Gpr $56^{-1-}$ mice were originally generated in a mixed C57BL/6/129 background. Both females and males were viable and fertile and no obvious defects in testis development were observed ( $\mathrm{Li}$ et al., 2008). However, after they were backcrossed onto a C57BL/6 background for ten generations, significantly fewer male $\mathrm{Fpr}_{56^{-/-}}$mice were able to produce progeny than their heterozygous siblings. Fertility tests were therefore performed to test whether GPR56 regulates male fertility in mice.

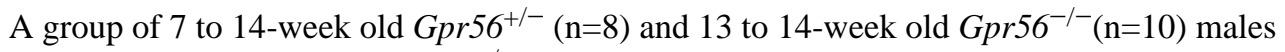
were housed together with $\mathrm{Fpr}^{56^{+/-}}$females of similar ages for 2.5 months (see Experimental Procedures for details). While all the $G p r 56^{+/-}$males produced progeny within this period, only 4 of the $G p r 56^{-1-}$ males (40\%) did so (Table 1), suggesting that GPR56 is important to maintain male fertility in mice. Male fertility is highly agedependent. To test whether the effects of GPR56 on male fertility also vary as mice age, we performed a second fertility test on older male mice (16 weeks). Only 2 of the $8 \mathrm{Gpr} 56^{-1-}$ males $(25 \%)$ produced progeny within the 1.6 months of breeding period, whereas all the five $\mathrm{Gpr}_{56^{+/-}}$males did (Table 1). These results confirmed the essential roles of GPR56 in male fertility and also suggested that the reduction in male fertility caused by the absence of GPR56 might exacerbate as mice age.

The effects of GPR56 on mouse fertility appear to be male-specific, since the fertilities of $G p r 56^{+/-}$and $G p r 56^{-/-}$females did not differ when they were tested using a similar approach (data not shown).

\section{Testis development is defective in Gpr56-/- males}

Testis is the major organ for sex determination and reproduction in males (Wilhelm et al., 2007). To test whether the reduced fertility observed in $\mathrm{Gpr}_{56^{-1-}}$ males is due to defective 
testis development, testes from $G p r 56^{-1-}$ male mice were harvested and found to be significantly smaller $(96 \pm 28 \mathrm{mg})$ than those from $\mathrm{Fpr}_{56^{+/-}}$mice of similar ages $(176 \pm 17$ $\mathrm{mg}$; Figure 2A and B). The levels of FSH, LH, and testosterone did not differ significantly between the $\mathrm{Gpr} 56^{+/-}$and $\mathrm{Gpr} 56^{-/-}$mice (Figure 2C, D, and E), suggesting that the reduced testis size in $\mathrm{Gpr} 56^{-/-}$mice is not due to alterations in hormonal regulation. Instead, histological analyses showed that seminiferous tubules in some regions of the Gpr $56^{-1-}$ testes were disrupted (Figure 3A). Consistently, immunohistochemical analyses using the antibody against SOX9 (Morais da Silva et al., 1996), another Sertoli cell marker, revealed that Sertoli cells were scattered in the defective areas of $\mathrm{Gpr}_{56^{-1-}}$ testes, instead of forming tubular structures as in $\mathrm{Fpr}_{56^{+-}}$testes. Seminiferous tubules provide the proper niche for the survival and maturation of spermatogonia. Their disruption has been shown to result in the reduction of male germ cells (Sharpe et al., 2003). To test whether deficiency in GPR56 leads to deceased germ cells, immunohistochemical analyses using an antibody against the spermatogonia -specific marker, GCNA1 (Wang and Enders, 1996), were performed on $\mathrm{Gpr} 5 \mathrm{6}^{+/-}$and $\mathrm{Gpr} 56^{-1-}$ testis sections. As predicted, loss of germ cells was observed in the defective areas of $G p r 56^{-1-}$ testes (Figure 3B) and likely contributes to the reduced fertility of $\mathrm{Gpr} 56^{-1-}$ male mice.

\section{Testis cords in Gpr56-/- embryos are disrupted in a polarized manner}

Sex determination in mice occurs at E11.5, when gonads differentiate into ovaries or testes (Wilhelm et al., 2007). In males, testis cords are formed at this stage by aggregation of Sertoli cells, which later expand and elongate into seminiferous tubules in adults. To understand whether the defects in testis development of $\mathrm{Gpr}_{56^{-1-}}$ mice originate during embryogenesis, sections from $\mathrm{Gpr} 56^{+/-}$and $\mathrm{Gpr} 56^{-/-}$embryonic gonads were immunostained with the anti-AMH antibody (Behringer et al., 1994). Apparent abnormal formation of testis cords was observed in $\mathrm{Fpr} 56^{-/-}$embryos from E14.5 to E18.5 (Figure 4). Interestingly, the defects were mostly observed on the mesonephric side of the gonad; the testis cords close to the coelomic side remained grossly intact (Figure 4).

To better visualize testis cord formation in $\mathrm{Gpr} 56^{-/-}$gonads, whole genital ridges from $\mathrm{Gpr}_{56^{+-}}$and $\mathrm{Gpr} 56^{-1-}$ male embryos were stained with the anti-SOX9 antibody (Morais da Silva et al., 1996). Distinct cords were observed at E13.5 in both $\mathrm{Gpr}_{56^{+/-}}$and $\mathrm{Gpr} 56^{-1-}$ gonads. However, at E16.5, the boundaries between testis cords in $G p r 56^{-1-}$ gonads appear to be less clear than those in $\mathrm{Gpr}_{56^{+/-}}$gonads (Supplementary Figure 2), and this is most prominent on the mesonephric side, consistent with our observations on sections (Figure 4).

\section{Basement membrane formation is defective in $\mathrm{Gpr} 56^{-/-}$gonads}

Testis cords and seminiferous tubules are surrounded by a layer of basement membrane, which separates the tubules from the interstitial space and protects the integrity of the tubules (Tung et al., 1984a; Kahsai et al., 1997). Disruptions of basement membrane have been associated with abnormal testis development (Salomon and Hedinger, 1982; Haider et al., 1999). To examine whether the basement membrane is defective in $\mathrm{Gpr}^{-1-} 6^{--}$testes, sections from $\mathrm{Gpr} 56^{+/-}$and $\mathrm{Gpr} 56^{-/-}$embryonic gonads or adult testes were stained with the antibody against laminin, a constitutive component of basement membrane. The results showed that while the basement membrane forms a continuous layer in $\mathrm{Gpr}_{56^{+/-}}$gonads, it is fragmented in $\mathrm{Fpr}_{56} \mathrm{6}^{-1-}$ gonads (Figure 5A). Again, this defect is concentrated on the mesonephric side of the testes. These results demonstrate that GPR56 is essential for proper basement membrane formation in testes.

To better examine the architectural changes associated with laminin alteration, coimmunostaining was performed on E16.5 $\mathrm{Gpr}^{-1-} 6^{-1}$ gonads using antibodies against AMH and laminin. Laminin continues to line around the Sertoli cells in these $\mathrm{Fpr}_{56}^{-/-}$gonads 
(Figure 5B), suggesting that the absence of GPR56 does not affect the deposition of laminin (and probably other basement membrane components) on Sertoli cells. Since the extracellular matrix (ECM) components of basement membrane are secreted by peritubular myoid (PM) cells and Sertoli cells in testes, and their assembly relies on the cooperation of both cell types (Tung et al., 1984a), the defective formation of basement membrane in Gpr $56^{-/-}$gonads could thus be due to the loss of association between PM cells and Sertoli cells. To test this, sections from $\mathrm{Gpr} 56^{+/+}$and $\mathrm{Gpr} 56^{-/-}$testes were stained with an antibody against smooth muscle actin (SMA), which strongly labels PM cells in testes (Tung and Fritz, 1990) (Figure 5C). In both wild-type testes and the intact areas of $\mathrm{Gpr}_{56^{-1-}}$ testes, the SMA-positive cells were found tightly associated with Sertoli cells at the periphery of testicular tubules (inset, top panel). In the defective areas of $\mathrm{Gpr}_{56^{-/}}$testes, SMA-positive cells were sparsely distributed, but appeared to grossly stay associated with Sertoli cells (inset, bottom panel), suggesting that disruption of basement membrane in $G p r 56^{-1-}$ testes may not be due to complete segregation of PM and Sertoli cells. It is possible, however, that the associated PM and Sertoli cells in $G p r 56^{-/-}$testes cannot maintain a functional relationship as in $\mathrm{Gpr}_{56^{+-}}$testes to direct proper basement membrane assembly, but our analyses were not sensitive enough to reveal these defects.

\section{Discussion}

Testis development is essential for male fertility and continuation of mammalian species (Wilhelm and Koopman, 2006). We report here that an atypical adhesion receptor, GPR56, regulates seminiferous tubule formation and male fertility in mice. In situ hybridization and immunohistochemical analyses revealed that GPR56 is expressed in Sertoli cells, indicating that GPR56 might direct the organization of Sertoli cells during testicular tubule formation. Absence of GPR56 leads to disruption of seminiferous tubule formation and increased sterility in male mice.

Our analyses showed that the defects in $G p r 56^{-1-}$ testes originate in embryos. In wild-type embryos, testis development occurs mainly in two steps. The first step includes sex determination and establishment of testis cords (Brennan and Capel, 2004; Wilhelm et al., 2007), and the second step involves testis maturation through cord remodeling (Combes et al., 2009). Disruption of the first step in mice often leads to not only defective testis development but also sex reversal in males (Capel, 2000; Colvin et al., 2001; Barrionuevo et al., 2006). This sex reversal phenotype was not observed in $\mathrm{Fpr}^{56^{-1-}}$ adult males (data not shown), arguing against a role for GPR56 at this initial step of testis development. Instead, testis cord disruptions occurred in $G p r 56^{-1-}$ embryos at E14.5 or older, indicating that GPR56 plays a role in the remodeling step of embryonic testis development.

As mice develop into adulthood, however, the proportion of defective seminiferous tubules in $\mathrm{Gpr}_{56^{-1-}}$ testes appeared to gradually decrease (see images in Figure 3 and Figure 5). We speculate that perhaps the normal tubules in $\mathrm{Gpr} 56^{-1-}$ embryonic gonads continue to extend and expand until adulthood, but their dysgenic counterparts have more limited capacity for doing so, leaving an impression of increased normal tubules in adult $\mathrm{Gpr}_{56^{-/-}}$testes as mice age. Spermatogenesis still occurs in the normal part of $\mathrm{Fpr}_{56^{-1-}}$ adult testes (Figure 3B), which may explain the partial fertility of $\mathrm{Fpr}_{56} \mathrm{C}^{-1-}$ male mice, but whether it occurs as efficiently as in wild-type testes is not clear.

The limited expansion of dysgenic tubules mentioned above could also explain the decreased weights of $\mathrm{Gpr} 56^{-1-}$ adult testes relative to those from $\mathrm{Gpr}_{56^{+/-}}$mice. However, during embryogenesis, $\mathrm{Gpr}_{56^{-/-}}$gonads were typically larger than $\mathrm{Gpr} 56^{+/-}$gonads of the same stages (Figures 1 and 4). Perhaps the distorted cords formed by $\mathrm{Fpr}_{56^{-/-}}$Sertoli cells 
occupy larger volumes than the elongated tubules from $\mathrm{Fpr}_{56^{+/-}}$Sertoli cells, giving an appearance of enlarged gonads.

One intriguing observation from our analyses is that the absence of GPR56 affects testis cord formation asymmetrically. Disruption of normal testis cord structure was consistently observed on the mesonephric side of $\mathrm{Gpr} 56^{-/-}$gonads, while cords on the coelomic side were grossly intact. These results suggest that remodeling of testis cords on the mesonephric side is dependent on the activity of GPR56, in contrast to the cords underneath the coelomic epithelium. This is consistent with a recent report that testis cords on the mesonephric side and on the coelomic side undergo distinct processes of remodeling during embryogenesis (Combes et al., 2009). While looped tubular structures result from the testis cords on the coelomic side, flattened and a coalesced network of Sertoli epithelium is formed on the mesonephric side. How these distinct remodeling processes are regulated has not been investigated. The specific effects of GPR56 on the remodeling of mesonephric cords leads us to speculate that GPR56 and its mediated signaling pathways set spatial and/or temporal constraints to define the boundary of these two types of testis cords. In the absence of GPR56, these constraints are perturbed and the coelomic testis cords closer to the mesonephros go through the process of remodeling that is characteristic of rete primordium and, consequently, appear as an interconnected network instead of distinct tubules.

Asymmetric tissue or organ morphogenesis is a highly regulated process occurring during the development of multicellular species, including mammals, flies, worms, and plants (Bryant and Mostov, 2008; Gonczy, 2008; Andrew and Ewald, 2009; Andrew and Ewald, 2010). It relies on the concerted interplay of signaling molecules that establish asymmetric cues to direct various cellular processes, including cell migration (Yu et al., 2005), cell-cell adhesion (Gumbiner, 2005), and cell-ECM adhesion (Miner and Yurchenco, 2004), eventually establishing polarities within each individual cell (Nejsum and Nelson, 2009) as well as across the plane of a tissue (planar cell polarity, PCP) (Jones and Chen, 2007; Wang and Nathans, 2007). Adhesion GPCRs have been shown to play active roles in many of the above processes (Stacey et al., 2003; Kwakkenbos et al., 2005; Wang et al., 2005; Xu et al., 2006; Li et al., 2008; Koirala et al., 2009). In particular, adhesion GPCRs are known to be involved in establishing PCP in tissues (Curtin et al., 2003; Yagi et al., 2007; Langenhan et al., 2009). PCP is established through oriented cell division and convergent extension, both of which are essential for tubule formation and elongation (Zallen and Blankenship, 2008). The apparent roles of GPR56 in testicular cord remodeling and its expression in Sertoli cells suggest that GPR56, like other adhesion GPCRs, might regulate PCP in the Sertoli epithelium to ensure proper testicular tubule extension.

The involvement of GPR56 in asymmetric testicular cord remodeling indicates that its function in male gonads might be polarized. However, our in situ hybridization and immunohistochemical analyses did not show apparent asymmetric distribution of either Gpr56 mRNA or protein in testes. Perhaps the ligand of GPR56 is expressed asymmetrically in the gonads and therefore activates the receptor in a polarized manner. We previously reported that the N-terminus of GPR56 interacts directly with tissue transglutaminase, TG2, in the extracellular matrix (Xu et al., 2006). TG2 colocalizes with laminin in mouse testes and its distribution was also altered in the absence of GPR56 (data not shown). However, no defects in testis development or male fertility have been observed in $\mathrm{Tg}^{-/-}$mice (unpublished data), suggesting that TG2 might not directly mediate the regulation of testis development by GPR56. The ligands that activate GPR56 in testes thus remain unknown.

Downstream signaling components of GPR56 are poorly defined. GPR56 has been shown to interact with $\mathrm{G} \alpha_{\mathrm{q}}$ (Little et al., 2004) and signal through $\mathrm{G} \alpha_{12 / 13}$ (Iguchi et al., 2008), but whether it directly binds to these $\mathrm{G}$ proteins and how the transmitted signals might affect 
testis development have not been studied. Signaling molecules, such as PDGFR- $\alpha$ (Brennan et al., 2003) and Deserted Hedgehog (DHH) (Clark et al., 2000; Pierucci-Alves et al., 2001; Yao et al., 2002), were known to regulate seminiferous tubule formation in mouse testes. Whether the pathways they regulate are perturbed in $\mathrm{Gpr}_{56^{-1-}}$ mice, leading to disrupted testis development, needs further investigations. However, the testicular defects in Pdgfr- $\alpha$ and $D h h$ mutant mice differ substantially from those in $\mathrm{Gpr}_{56^{-1-}}$ mice. For example, none of them exhibited polarized defects in cord formation as observed in the $G p r 56^{-1-}$ gonads (Yao et al., 2002; Brennan et al., 2003). In addition, whereas the $P d g f r-\alpha^{-1-}$ mice were embryonic lethal (Soriano, 1994), the $\mathrm{Dhh}^{-1-}$ mice developed to full-term (Bitgood et al., 1996) and showed not only defects in seminiferous tubule formation but also sex reversal (Clark et al., 2000), which does not occur in the $G p r 56^{-1-}$ mice. These differences suggest that any effects of GPR56 on the PDGF or DHH pathway during testis development are likely restricted to certain cell types and/or at a particular developmental stage.

Recently, we and others revealed the roles of GPR56 in vesicle trafficking of secretory proteins. We reported that GPR56 inhibits the secretion of vascular endothelial growth factor (VEGF) in melanoma cells (manuscript submitted), and Collinet et al. identified GPR56 as one of the factors that regulate endocytosis of EGF and transferring (Collinet et al., 2010). Vesicle trafficking is a critical factor during the establishment of cell polarity (Rodriguez-Boulan et al., 2005; Mellman and Nelson, 2008). Many of the factors that regulate cell polarity need to be transported asymmetrically and thus rely on recognition and specific targeting by the vesicular trafficking system. It is plausible that GPR56 is involved in polarized distribution or secretion of molecules that are key for formation of the basement membrane and alignment of Sertoli cells during testis cord remodeling. Whether this is the case and whether other adhesion GPCRs function through a similar mechanism will be interesting directions for future investigations.

In conclusion, we report here an essential role of an adhesion GPCR, GPR56, in mouse testis development and fertility. Our analyses reveal that it affects asymmetric cord remodeling during gonad development in embryos. We propose that GPR56 may influence testis tubule extension by regulating cell polarity-related processes, one of which could be polarized vesicle trafficking.

\section{Experimental Procedures}

\section{Mice}

The $G p r 56^{-1-}$ mice, in which the exons 2 and 3 of the Gpr56 gene were replaced by a lacZneomycin cassette, were obtained from Genentech Inc. (Li et al., 2008) and subsequently backcrossed onto a C57BL/6 background for ten generations. The null mice were maintained by crosses between $\mathrm{Gpr}_{56^{-/-}}$females and $\mathrm{Gpr} 56^{+/-}$males. Genotyping was carried out by PCR using mouse genomic DNA as the template and the primers: $5^{\prime}-$ GCTTCATCTTCTCCTTCCAC-3', 5'-AAAGTAGCTAAGATGCTCTCC-3', and 5'GCAGCGCATCGCCTTCTATC-3'. The expected size of the PCR product is $\sim 260 \mathrm{bp}$ for the wild-type allele and $\sim 370$ bp for the null allele.

All mice were housed in the animal facility at the University of Rochester Medical Center. Animal care and procedures were conducted in accordance with the guidelines from the Division of Laboratory Animal Medicine.

\section{Fertility Tests}

$8 \mathrm{Gpr}^{\circ 6^{+/-}}$mice of 7 to 14 weeks of age and $10 \mathrm{Gpr}^{-1-} 6^{-1-}$ male mice of 13 or 14 weeks of age, or $5 \mathrm{Gpr}^{\circ 6^{+/-}}$and $8 \mathrm{Gpr} 56^{-/-}$male mice of the same age (16 weeks), were bred with $\mathrm{Gpr}_{56^{+/-}}$females for 2.5 months, or 1.6 months, respectively. For the first group of mice, 
two 7-week old, two 12-week old, two 13-week old, and two 14-week old $\mathrm{Gpr} 56^{+/-}$mice were included, and four 13-week old and six 14-week old $\mathrm{Fpr} 56^{-1-}$ mice were included. Each of male mice was bred with a different female mouse and each breeding pair was examined weekly for newborns. The males that produced pups within the examined period were considered fertile.

\section{Hormone Measurements}

Whole blood from 10-week old $\mathrm{Gpr} 56^{+/-}$and $\mathrm{Gpr} 56^{-/-}$mice was obtained by cardiac puncture immediately after euthanasia by $\mathrm{CO}_{2}$ inhalation. The samples were allowed to clot at room temperature for $30 \mathrm{~min}$ before centrifugation for serum collection. The levels of FSH, LH, and testosterone were measured by radioimmunoassay (for FSH and testosterone) or two-site sandwich immunoassay (for LH) by the Ligand Assay and Analysis Core Laboratory at the Center for Research in Reproduction of University of Virginia (Charlottesville, VA).

\section{Histological and Immunohistochemical Analyses}

Testes from 10-week old $\mathrm{Gpr} 56^{+/-}$and $\mathrm{Gpr}_{56^{-/-}}$male mice were harvested and weighed. They were fixed in formalin overnight, embedded in paraffin, sectioned and stained with hematoxylin and eosin for histological analyses.

For immunohistochemical analyses, sections processed as described above were de-waxed, boiled for $30 \mathrm{~min}$ in sodium citrate buffer for antigen retrieval, and then incubated with the rat anti-GCNA1 antibody (1:50, a gift from Dr. George Enders, University of Kansas), rabbit anti-SOX9 antibody (1:100, Chemicon), or the mouse anti-SMA antibody (1:400, Sigma-Aldrich) at $4{ }^{\circ} \mathrm{C}$ overnight. The signals were detected with the relevant biotinylated secondary antibodies and the Vectastain ABC kit and developed using the Vector VIP Substrate (Vector Laboratories, CA). Methyl green was applied as counterstain (Vector Laboratories).

For embryonic studies, $\mathrm{Gpr} 56^{-/-}$female mice were mated with $\mathrm{Gpr} 56^{+/-}$male mice. Embryonic stages were calculated from the day when vaginal plugs were detected in the females (E0.5). Genotyping using primers specific to the Sry gene (5'TTGTCTAGAGAGCATGGAGGGCCATGTCAA-3' and 5'CCACTCCTCTGTGACACTTTAGCCCTCCGA-3') was performed to determine the gender of the embryos. Male embryos were used for the subsequent immunohistochemical analyses. Specifically, genital ridges were dissected from embryos and fixed in $4 \%$ paraformaldehyde for two hours at $4{ }^{\circ} \mathrm{C}$. After being passed through $30 \%$ sucrose, they were frozen in O.C.T and sectioned. The sections were stained with rabbit anti-laminin antibody (1:1000, Sigma-Aldrich), anti-AMH antibody (1:50, MIS(C-20), Santa Cruz

Biotechnology), or rabbit anti-GPRC antibody (1: 300) (Xu et al., 2006) at $4{ }^{\circ} \mathrm{C}$ overnight, followed by detection with Alexa 488 - or Alexa 594 conjugated secondary antibodies. Images were captured using a SPOT camera and processed in AdobePhotoshop.

\section{Whole Mount in situ Hybridization and Immunostaining}

For in situ hybridization, mouse genital ridges were isolated from E16.5 male embryos and fixed in $4 \%$ PFA at $4{ }^{\circ} \mathrm{C}$ overnight before being probed with the digoxigenin-labeled Gpr56 antisense RNA probe. The hybridization signal was detected using alkaline phosphataseconjugated anti-DIG antibody (Roche Applied Science) with NBT/BCIP as the substrate (Roche Applied Science). The Gpr56-specific antisense RNA probe binds to exons 2 and 3 of mouse Gpr56, which are deleted in the $G p r 56^{-1-}$ mice, and was synthesized by in vitro transcription using the DIG RNA labeling kit (Roche Applied Science). The template for the in vitro transcription was amplified from the mouse Gpr56 cDNA (IMAGE ID 3709247) by 
PCR using 5'-GTAGGAGTATAATGGCTGTC-3' and 5'-

TGTGGAAGGAGAAGATGAAG-3' as primers.

For whole mount immunostaining, embryonic gonads were fixed in $4 \%$ paraformaldehyde at $4^{\circ} \mathrm{C}$ overnight, blocked in PBSTG (0.1\% Triton X-100 and $10 \%$ normal goat serum in PBS) for $4 \mathrm{hrs}$, and then incubated with the rabbit anti-SOX9 antibody $(1: 200)$ at $4{ }^{\circ} \mathrm{C}$ overnight.

After being washed three times over 3 hrs in PBST (0.1\% Triton X-100 in PBS) and blocked again in PBSTG for $2 \mathrm{hrs,} \mathrm{the} \mathrm{gonads} \mathrm{were} \mathrm{incubated} \mathrm{with} \mathrm{Alexa} \mathrm{488-conjugated} \mathrm{goat} \mathrm{anti-}$ rabbit secondary antibody (1:200, Invitrogen) at $4{ }^{\circ} \mathrm{C}$ overnight and then washed four times over $4 \mathrm{hrs}$ in PBST before being mounted in $60 \%$ glycerol and imaged on a confocal microscope (Leica Microsystems Inc., IL).

\section{Isolation of Sertoli Cells and Immunoblot Analysis}

Testes from two 4-week old male mice were collected and processed to isolate Sertoli cells as described previously (Tung et al., 1984b). Briefly, testes were decapsulated and digested with $0.25 \%$ trypsin and $10 \mathrm{mg} / \mathrm{ml}$ DNAase for $25 \mathrm{~min}$ at $32{ }^{\circ} \mathrm{C}$ before the addition of soybean trypsin inhibitor. Seminiferous tubules were settled at the bottom of the suspension after a few minutes and were resuspended in $10 \mathrm{mls}$ of HBSS (Invitrogen) containing $1 \mathrm{mg} /$ $\mathrm{ml}$ collagenase for $25 \mathrm{~min}$ at $32{ }^{\circ} \mathrm{C}$. The fragmented seminiferous tubules were further digested by $1 \mathrm{mg} / \mathrm{ml}$ bovine testes hyaluronidase at $32^{\circ} \mathrm{C}$ for $25 \mathrm{~min}$. Sertoli cell aggregates were released and were further purified by low-speed centrifugation $(60 \times \mathrm{g})$ and two washes with $\mathrm{Ca} / \mathrm{Mg}$-free HBSS before being plated in the serum-free derived Eagle's minimal essential medium (SFDM) containing $1 \mathrm{nM}$ hydrocortisone, $22 \mathrm{mM}$ sodium lactate, $200 \mathrm{ng} / \mathrm{ml}$ vitamin E, $5 \mathrm{mg} / \mathrm{ml}$ apo-transferrin, $10 \mathrm{nM}$ beta-estradiol, $50 \mathrm{ng} / \mathrm{ml}$ vitamin A, 2 $\mathrm{ug} / \mathrm{ml}$ insulin, $5 \mathrm{ng} / \mathrm{ml}$ sodium selenate, $1 \mathrm{mM}$ sodium pyruvate (Invitrogen), $10 \mathrm{nM}$ testosterone, $50 \mathrm{ng} / \mathrm{ml}$ vitamin C, $2 \mathrm{mM}$ glutamine (Invitrogen), $100 \mathrm{U} / \mathrm{ml}$ penicillin (Invitrogen), $100 \mathrm{mg} / \mathrm{ml}$ streptomycin (Invitrogen), $1 \mathrm{mM}$ non-essential amino acids (Invitrogen), $10 \mathrm{ng} / \mathrm{ml}$ EGF (ProSpec-Tany TechnoGene Ltd., Israel) and $100 \mathrm{mIU} / \mathrm{ml} \mathrm{FSH}$ (Hadley et al., 1985). The medium was changed every two days. Non-adherent cells including germ cells were consequently removed after a few days. All the above ingredients were purchased from Sigma-Aldrich Corp. unless otherwise specified.

After being cultured for one week, the purity of Sertoli cells were tested by immunostaining with the anti-Sox 9 antibodies and $>80 \%$ SOX-9 positive cells were typically observed in the preparations. For western blot analyses, the purified Sertoli cells were lysed in laemmlli buffer and separated on a $12 \%$ SDS-polyacrylamide gel and probed by the rabbit anti-GPRC antibody (1:300), the rabbit anti-SOX9 antibody (1:100), and the mouse anti-GAPDH antibody. Signals were amplified with relevant HRP-conjugated secondary antibodies and detected with the ECL reagent (Pelkin Elmer, MA). These analyses were repeated independently by two investigators.

\section{Data Processing and Statistics}

Testis weights and hormone measurements were processed using the Microsoft Excel software. Student's t-test (http://www.physics.csbsju.edu/stats/t-test.html) was performed to calculate the statistical significance of the differences.

\section{Supplementary Material}

Refer to Web version on PubMed Central for supplementary material. 


\section{Acknowledgments}

We thank Dr. Catherine Ovitt (University of Rochester), Dr. Sunny Wong (UCSF), Dr. Dirk Bohman (University of Rochester), and Dr. Blanche Capel (Duke University) for critical reading of the manuscript. We also thank Brad Martin (University of Rochester) and Denise Crowley (M.I.T.) for technical assistance, Drs. Blanche Capel (Duke University) and George Gerton (University of Pennsylvania) for stimulating discussions, Dr. Sophie Astrof (Cornell University) and Dr. Rulang Jiang (University of Rochester) for protocols on in situ hybridization, Drs. Kate Ackerman and Catherine Ovitt (University of Rochester) for sharing equipment, and Dr George Enders (University of Kansas) for the anti-GCNA1 antibody. We are grateful for the support from Dr. Richard O. Hynes (M.I.T.), in whose laboratory this work was initiated. Funding for this study was partly provided by Howard Hughes Medical Institute (to R.O.H.), NIH grant U54-CA126515 (to R.O.H.), the start-up fund for new investigators (University of Rochester, to L.X.) and the Ruth L. Kirschstein National Research Service Award (to L.X.).

\section{References}

Andrew DJ, Ewald AJ. Morphogenesis of epithelial tubes: Insights into tube formation, elongation, and elaboration. Dev Biol. 2009

Andrew DJ, Ewald AJ. Morphogenesis of epithelial tubes: Insights into tube formation, elongation, and elaboration. Dev Biol. 2010; 341:34-55. [PubMed: 19778532]

Barrionuevo F, Bagheri-Fam S, Klattig J, Kist R, Taketo MM, Englert C, Scherer G. Homozygous inactivation of Sox9 causes complete XY sex reversal in mice. Biol Reprod. 2006; 74:195-201. [PubMed: 16207837]

Behringer RR, Finegold MJ, Cate RL. Mullerian-inhibiting substance function during mammalian sexual development. Cell. 1994; 79:415-425. [PubMed: 7954809]

Bitgood MJ, Shen L, McMahon AP. Sertoli cell signaling by Desert hedgehog regulates the male germline. Curr Biol. 1996; 6:298-304. [PubMed: 8805249]

Brennan J, Capel B. One tissue, two fates: molecular genetic events that underlie testis versus ovary development. Nat Rev Genet. 2004; 5:509-521. [PubMed: 15211353]

Brennan J, Tilmann C, Capel B. Pdgfr-alpha mediates testis cord organization and fetal Leydig cell development in the XY gonad. Genes Dev. 2003; 17:800-810. [PubMed: 12651897]

Bryant DM, Mostov KE. From cells to organs: building polarized tissue. Nat Rev Mol Cell Biol. 2008; 9:887-901. [PubMed: 18946477]

Buehr M, Gu S, McLaren A. Mesonephric contribution to testis differentiation in the fetal mouse. Development. 1993; 117:273-281. [PubMed: 8223251]

Capel B. The battle of the sexes. Mech Dev. 2000; 92:89-103. [PubMed: 10704890]

Clark AM, Garland KK, Russell LD. Desert hedgehog (Dhh) gene is required in the mouse testis for formation of adult-type Leydig cells and normal development of peritubular cells and seminiferous tubules. Biol Reprod. 2000; 63:1825-1838. [PubMed: 11090455]

Collinet C, Stoter M, Bradshaw CR, Samusik N, Rink JC, Kenski D, Habermann B, Buchholz F, Henschel R, Mueller MS, Nagel WE, Fava E, Kalaidzidis Y, Zerial M. Systems survey of endocytosis by multiparametric image analysis. Nature. 2010; 464:243-249. [PubMed: 20190736]

Colvin JS, Green RP, Schmahl J, Capel B, Ornitz DM. Male-to-female sex reversal in mice lacking fibroblast growth factor 9. Cell. 2001; 104:875-889. [PubMed: 11290325]

Combes AN, Lesieur E, Harley VR, Sinclair AH, Little MH, Wilhelm D, Koopman P. Threedimensional visualization of testis cord morphogenesis, a novel tubulogenic mechanism in development. Dev Dyn. 2009; 238:1033-1041. [PubMed: 19334288]

Curtin JA, Quint E, Tsipouri V, Arkell RM, Cattanach B, Copp AJ, Henderson DJ, Spurr N, Stanier P, Fisher EM, Nolan PM, Steel KP, Brown SD, Gray IC, Murdoch JN. Mutation of Celsr1 disrupts planar polarity of inner ear hair cells and causes severe neural tube defects in the mouse. Curr Biol. 2003; 13:1129-1133. [PubMed: 12842012]

Gonczy P. Mechanisms of asymmetric cell division: flies and worms pave the way. Nat Rev Mol Cell Biol. 2008; 9:355-366. [PubMed: 18431399]

Gumbiner BM. Regulation of cadherin-mediated adhesion in morphogenesis. Nat Rev Mol Cell Biol. 2005; 6:622-634. [PubMed: 16025097] 
Hadley MA, Byers SW, Suarez-Quian CA, Kleinman HK, Dym M. Extracellular matrix regulates Sertoli cell differentiation, testicular cord formation, and germ cell development in vitro. J Cell Biol. 1985; 101:1511-1522. [PubMed: 4044644]

Haider SG, Talati J, Servos G. Ultrastructure of peritubular tissue in association with tubular hyalinization in human testis. Tissue Cell. 1999; 31:90-98. [PubMed: 10368990]

Iguchi T, Sakata K, Yoshizaki K, Tago K, Mizuno N, Itoh H. Orphan G protein-coupled receptor GPR56 regulates neural progenitor cell migration via a $\mathrm{G}$ alpha 12/13 and Rho pathway. J Biol Chem. 2008; 283:14469-14478. [PubMed: 18378689]

Jones C, Chen P. Planar cell polarity signaling in vertebrates. Bioessays. 2007; 29:120-132. [PubMed: 17226800]

Kahsai TZ, Enders GC, Gunwar S, Brunmark C, Wieslander J, Kalluri R, Zhou J, Noelken ME, Hudson BG. Seminiferous tubule basement membrane. Composition and organization of type IV collagen chains, and the linkage of alpha3(IV) and alpha5(IV) chains. J Biol Chem. 1997; 272:17023-17032. [PubMed: 9202017]

Koirala S, Jin Z, Piao X, Corfas G. GPR56-regulated granule cell adhesion is essential for rostral cerebellar development. J Neurosci. 2009; 29:7439-7449. [PubMed: 19515912]

Kwakkenbos MJ, Pouwels W, Matmati M, Stacey M, Lin HH, Gordon S, van Lier RA, Hamann J. Expression of the largest CD97 and EMR2 isoforms on leukocytes facilitates a specific interaction with chondroitin sulfate on B cells. J Leukoc Biol. 2005; 77:112-119. [PubMed: 15498814]

Langenhan T, Promel S, Mestek L, Esmaeili B, Waller-Evans H, Hennig C, Kohara Y, Avery L, Vakonakis I, Schnabel R, Russ AP. Latrophilin signaling links anterior-posterior tissue polarity and oriented cell divisions in the C. elegans embryo. Dev Cell. 2009; 17:494-504. [PubMed: 19853563]

Li S, Jin Z, Koirala S, Bu L, Xu L, Hynes RO, Walsh CA, Corfas G, Piao X. GPR56 regulates pial basement membrane integrity and cortical lamination. J Neurosci. 2008; 28:5817-5826. [PubMed: 18509043]

Little KD, Hemler ME, Stipp CS. Dynamic regulation of a GPCR-tetraspanin-G protein complex on intact cells: central role of CD81 in facilitating GPR56-Galpha q/11 association. Mol Biol Cell. 2004; 15:2375-2387. [PubMed: 15004227]

Martineau J, Nordqvist K, Tilmann C, Lovell-Badge R, Capel B. Male-specific cell migration into the developing gonad. Curr Biol. 1997; 7:958-968. [PubMed: 9382843]

McLaren A. Development of the mammalian gonad: the fate of the supporting cell lineage. Bioessays. 1991; 13:151-156. [PubMed: 1859392]

Mellman I, Nelson WJ. Coordinated protein sorting, targeting and distribution in polarized cells. Nat Rev Mol Cell Biol. 2008; 9:833-845. [PubMed: 18946473]

Miner JH, Yurchenco PD. Laminin functions in tissue morphogenesis. Annu Rev Cell Dev Biol. 2004; 20:255-284. [PubMed: 15473841]

Morais da Silva S, Hacker A, Harley V, Goodfellow P, Swain A, Lovell-Badge R. Sox9 expression during gonadal development implies a conserved role for the gene in testis differentiation in mammals and birds. Nat Genet. 1996; 14:62-68. [PubMed: 8782821]

Nejsum LN, Nelson WJ. Epithelial cell surface polarity: the early steps. Front Biosci. 2009; 14:10881098. [PubMed: 19273117]

O’Shaughnessy PJ, Morris ID, Huhtaniemi I, Baker PJ, Abel MH. Role of androgen and gonadotrophins in the development and function of the Sertoli cells and Leydig cells: data from mutant and genetically modified mice. Mol Cell Endocrinol. 2009; 306:2-8. [PubMed: 19059463]

Piao X, Hill RS, Bodell A, Chang BS, Basel-Vanagaite L, Straussberg R, Dobyns WB, Qasrawi B, Winter RM, Innes AM, Voit T, Ross ME, Michaud JL, Descarie JC, Barkovich AJ, Walsh CA. G protein-coupled receptor-dependent development of human frontal cortex. Science. 2004; 303:2033-2036. [PubMed: 15044805]

Pierucci-Alves F, Clark AM, Russell LD. A developmental study of the Desert hedgehog-null mouse testis. Biol Reprod. 2001; 65:1392-1402. [PubMed: 11673255]

Rodriguez-Boulan E, Kreitzer G, Musch A. Organization of vesicular trafficking in epithelia. Nat Rev Mol Cell Biol. 2005; 6:233-247. [PubMed: 15738988] 
Salomon F, Hedinger CE. Abnormal basement membrane structures of seminiferous tubules in infertile men. Lab Invest. 1982; 47:543-554. [PubMed: 7144137]

Sharpe RM, McKinnell C, Kivlin C, Fisher JS. Proliferation and functional maturation of Sertoli cells, and their relevance to disorders of testis function in adulthood. Reproduction. 2003; 125:769-784. [PubMed: 12773099]

Shima JE, McLean DJ, McCarrey JR, Griswold MD. The murine testicular transcriptome: characterizing gene expression in the testis during the progression of spermatogenesis. Biol Reprod. 2004; 71:319-330. [PubMed: 15028632]

Soriano P. Abnormal kidney development and hematological disorders in PDGF beta-receptor mutant mice. Genes Dev. 1994; 8:1888-1896. [PubMed: 7958864]

Stacey M, Chang GW, Davies JQ, Kwakkenbos MJ, Sanderson RD, Hamann J, Gordon S, Lin HH. The epidermal growth factor-like domains of the human EMR2 receptor mediate cell attachment through chondroitin sulfate glycosaminoglycans. Blood. 2003; 102:2916-2924. [PubMed: 12829604]

Tilmann C, Capel B. Mesonephric cell migration induces testis cord formation and Sertoli cell differentiation in the mammalian gonad. Development. 1999; 126:2883-2890. [PubMed: 10357932]

Tung PS, Fritz IB. Characterization of rat testicular peritubular myoid cells in culture: alpha-smooth muscle isoactin is a specific differentiation marker. Biol Reprod. 1990; 42:351-365. [PubMed: 2186815]

Tung PS, Skinner MK, Fritz IB. Cooperativity between Sertoli cells and peritubular myoid cells in the formation of the basal lamina in the seminiferous tubule. Ann N Y Acad Sci. 1984a; 438:435-446. [PubMed: 6598327]

Tung PS, Skinner MK, Fritz IB. Fibronectin synthesis is a marker for peritubular cell contaminants in Sertoli cell-enriched cultures. Biol Reprod. 1984b; 30:199-211. [PubMed: 6199048]

Wang D, Enders GC. Expression of a specific mouse germ cell nuclear antigen (GCNA1) by early embryonic testicular teratoma cells in 129/Sv-S1/+ mice. Cancer Lett. 1996; 100:31-36. [PubMed: 8620450]

Wang T, Ward Y, Tian L, Lake R, Guedez L, Stetler-Stevenson WG, Kelly K. CD97, an adhesion receptor on inflammatory cells, stimulates angiogenesis through binding integrin counterreceptors on endothelial cells. Blood. 2005; 105:2836-2844. [PubMed: 15576472]

Wang Y, Nathans J. Tissue/planar cell polarity in vertebrates: new insights and new questions. Development. 2007; 134:647-658. [PubMed: 17259302]

Whittaker CA, Bergeron KF, Whittle J, Brandhorst BP, Burke RD, Hynes RO. The echinoderm adhesome. Dev Biol. 2006; 300:252-266. [PubMed: 16950242]

Wilhelm D, Koopman P. The makings of maleness: towards an integrated view of male sexual development. Nat Rev Genet. 2006; 7:620-631. [PubMed: 16832429]

Wilhelm D, Palmer S, Koopman P. Sex determination and gonadal development in mammals. Physiol Rev. 2007; 87:1-28. [PubMed: 17237341]

Xu L, Begum S, Hearn JD, Hynes RO. GPR56, an atypical G protein-coupled receptor, binds tissue transglutaminase, TG2, and inhibits melanoma tumor growth and metastasis. Proc Natl Acad Sci U S A. 2006; 103:9023-9028. [PubMed: 16757564]

Yagi H, Tokano H, Maeda M, Takabayashi T, Nagano T, Kiyama H, Fujieda S, Kitamura K, Sato M. Vlgr1 is required for proper stereocilia maturation of cochlear hair cells. Genes Cells. 2007; 12:235-250. [PubMed: 17295842]

Yao HH, Whoriskey W, Capel B. Desert Hedgehog/Patched 1 signaling specifies fetal Leydig cell fate in testis organogenesis. Genes Dev. 2002; 16:1433-1440. [PubMed: 12050120]

Yona S, Lin HH, Siu WO, Gordon S, Stacey M. Adhesion-GPCRs: emerging roles for novel receptors. Trends Biochem Sci. 2008; 33:491-500. [PubMed: 18789697]

Yu W, Datta A, Leroy P, O’Brien LE, Mak G, Jou TS, Matlin KS, Mostov KE, Zegers MM. Beta1integrin orients epithelial polarity via Rac1 and laminin. Mol Biol Cell. 2005; 16:433-445. [PubMed: 15574881]

Zallen JA, Blankenship JT. Multicellular dynamics during epithelial elongation. Semin Cell Dev Biol. 2008; 19:263-270. [PubMed: 18343171] 
A.

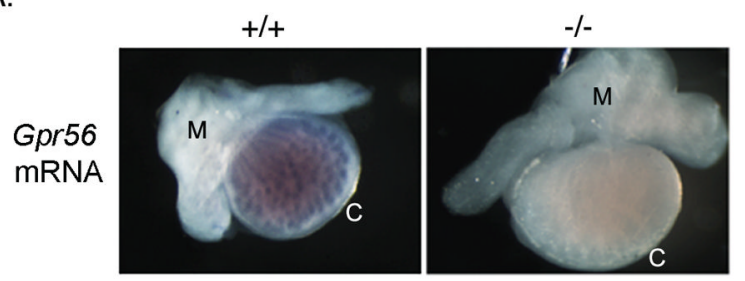

C. Sertoli Cells Gpr56 +/- -/-
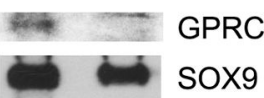

SOX9

GAPDH

B.

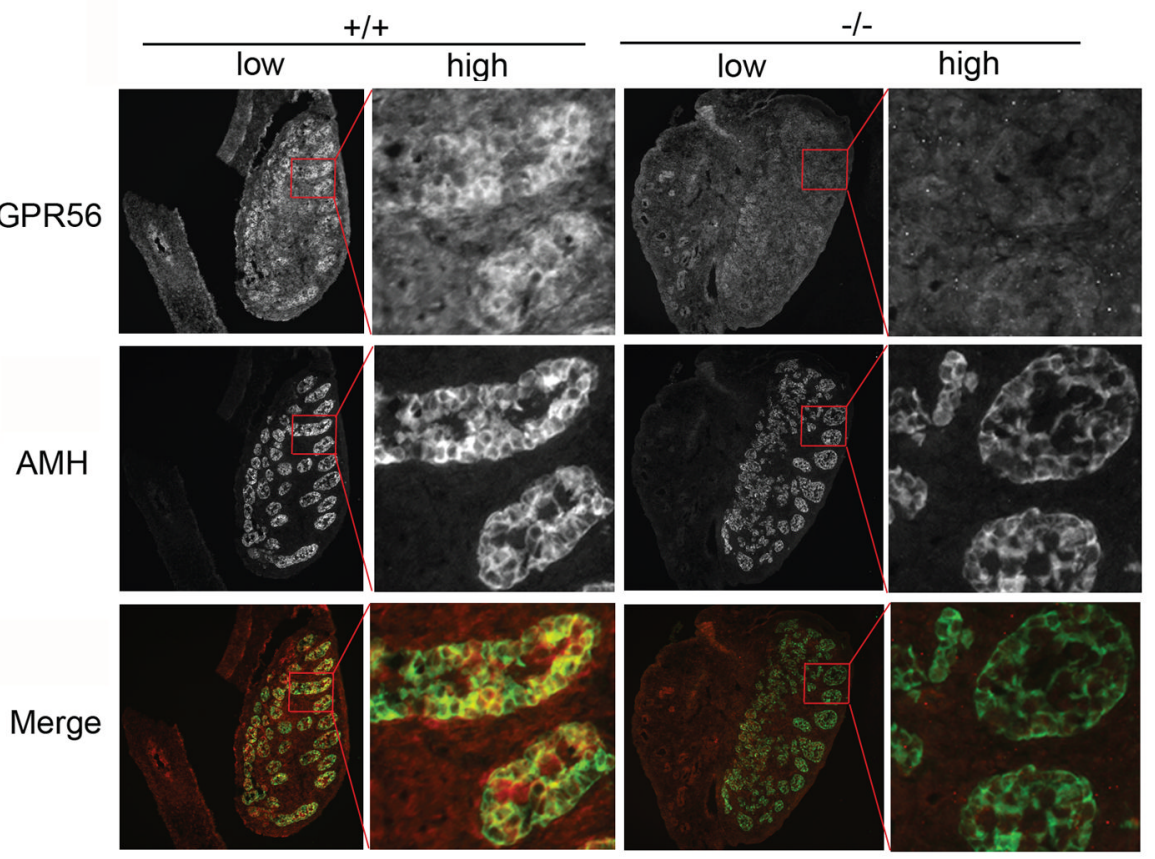

Figure 1. Gpr56 mRNA and its encoded protein are expressed in Sertoli cells comprising the testis cords of mouse embryos

A. The distribution patterns of Gpr56 mRNA in the genital ridges from E16.5 Gpr56 $6^{+/+}(\mathrm{n}=$ $3)$ and $G p r 56^{-/-}(\mathrm{n}=3)$ embryos were examined by in situ hybridization using Gpr56 antisense probe. The probe specifically detected Gpr56 mRNA in wild-type but not in testis cords from Gpr $56^{-/-}$mice. Gpr56 $6^{-/-}$gonads often appear larger than $\mathrm{Gpr}_{56^{+/-}}$gonads of the same stage. The reason is not known. M: mesonephros; C: coelomic epithelium.

B. The distribution pattern of GPR56 protein in the genital ridges from E14.5 Gpr56 ${ }^{+/+}(\mathrm{n}=$ 4) and $\operatorname{Fpr}_{56} 6^{-1-}(\mathrm{n}=4)$ embryos was examined by co-immunostaining with the anti-GPR56 antibody (red) and anti-AMH antibody (green), which labels Sertoli cells. Colocalization of GPR56 and AMH was observed in the wild-type but not in the $G p r 56^{-/-}$gonads. Images of whole genital ridges are shown in low magnification on the left, with an area in each gonad (red box) shown in high magnification on the right.

C. GPR56 was specifically detected in the $\mathrm{Fpr}_{56^{+/-}}$Sertoli cell preparations. Sertoli cells were isolated from two 4-week old $\mathrm{Gpr} 56^{+/-}$and $\mathrm{Gpr} 56^{-/-}$mice, lysed, and probed with the anti-GPR56 antibody and the anti-SOX9 antibody on a western blot. The level of GAPDH in each lysate was used as the loading control. 
A.

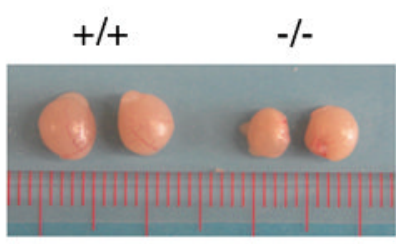

C.

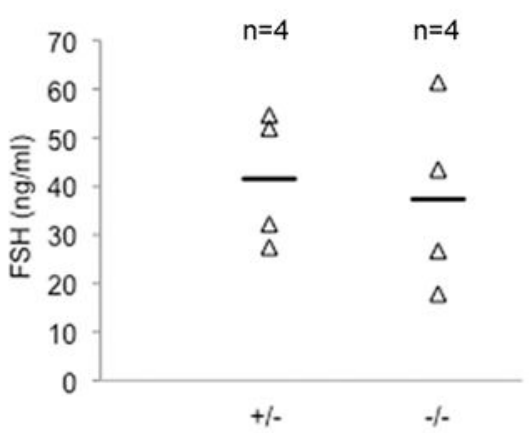

E.

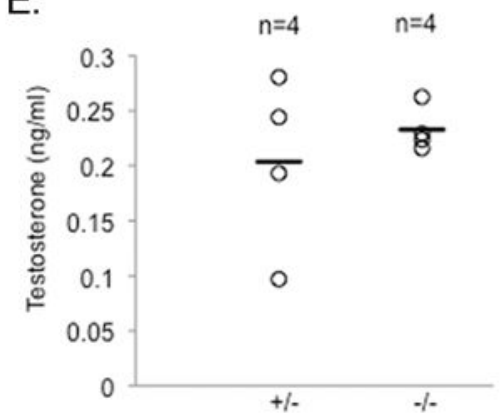

B.

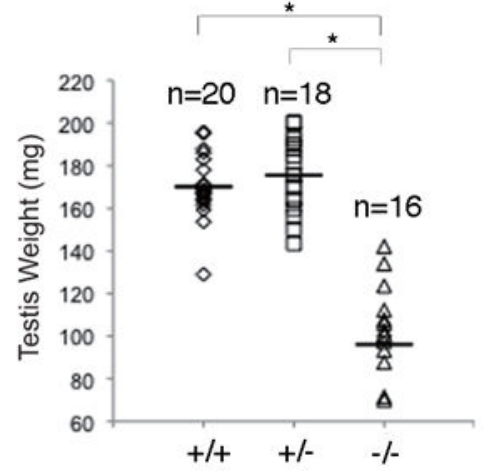

D.

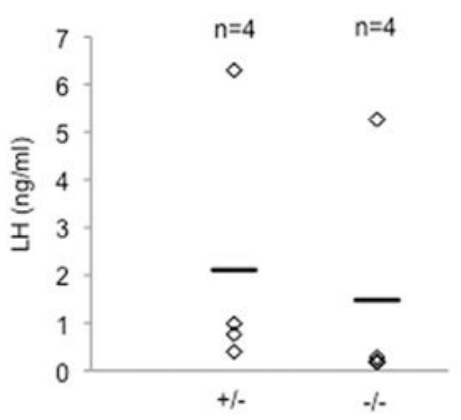

Figure 2. Testis development is impaired in $\mathrm{Gpr}^{-1-}$ mice

The sizes (A) and weights (B) of $G p r 56^{-/-}$testes are significantly reduced compared with $G p r 56^{+/-}$or wild-type testes. This defect in testis development is unlikely due to hormonal deregulation, since the levels of FSH (C), LH (D), and testosterone (E) do not differ significantly between the $\mathrm{Gpr} 56^{+/-}$and $\mathrm{Gpr} 56^{-/-}$mice. *: $p<0.0001$, Student's t-test. 
A.

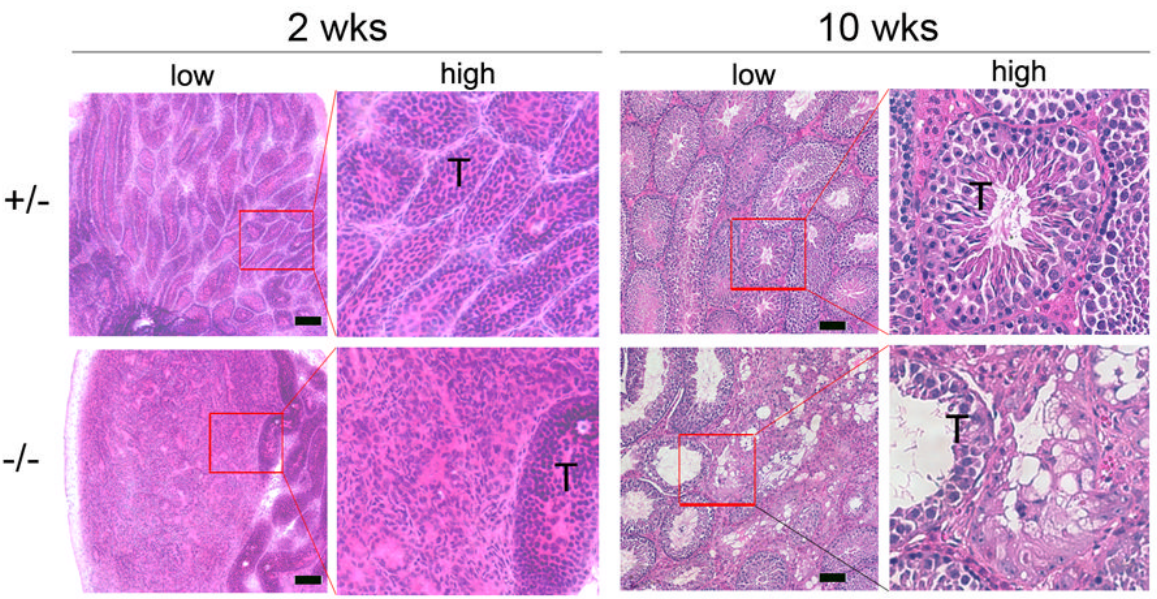

B.

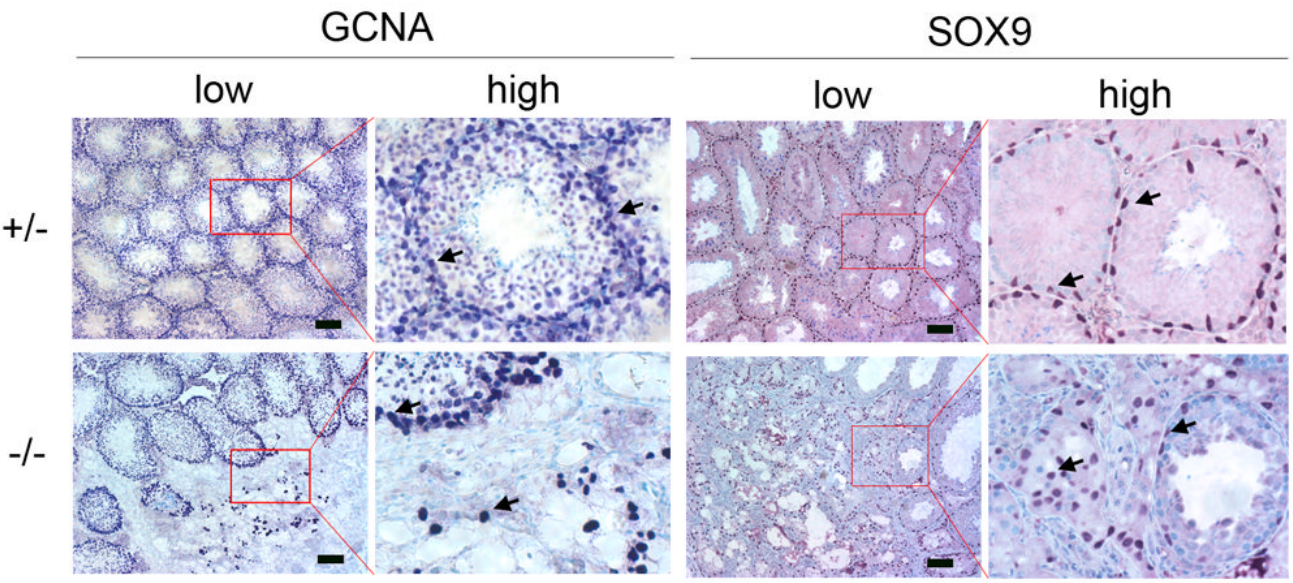

Figure 3. Disruption of seminiferous tubule formation in $\mathrm{Gpr}^{-1-}$ testes

A. H\&E staining of testis sections from 2 -week old $(\mathrm{n}=3)$ or 10 -week old $(\mathrm{n}>8) \mathrm{Gpr}^{\mathrm{f}} 6^{+/-}$ and $G p r 56^{-1-}$ mice. A disruption of seminiferous tubules (T) in $G p r 56^{-1-}$ sections is apparent at both stages. Images of low magnifications are shown on the left, with some areas (red box) shown in high magnifications on the right.

B. The distribution of germ cells and Sertoli cells are abnormal in the $G p r 56^{-1-}$ testes. Sections of testes from 10-week old $\operatorname{Fpr}_{56^{+/-}}(\mathrm{n}=4)$ and $\mathrm{Gpr}^{-1-}$ mice $(\mathrm{n}=4)$ were stained with the anti-GCNA1 antibody to detect germ cells (arrows) and the anti-SOX9 antibody to detect Sertoli cells (arrows). Images of low magnifications are shown on the left, with some areas (red box) shown in high magnifications on the right. Depletion of germ cells and disorganized localization of Sertoli cells are seen in the disrupted areas of the

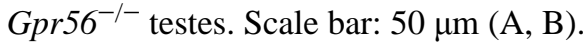




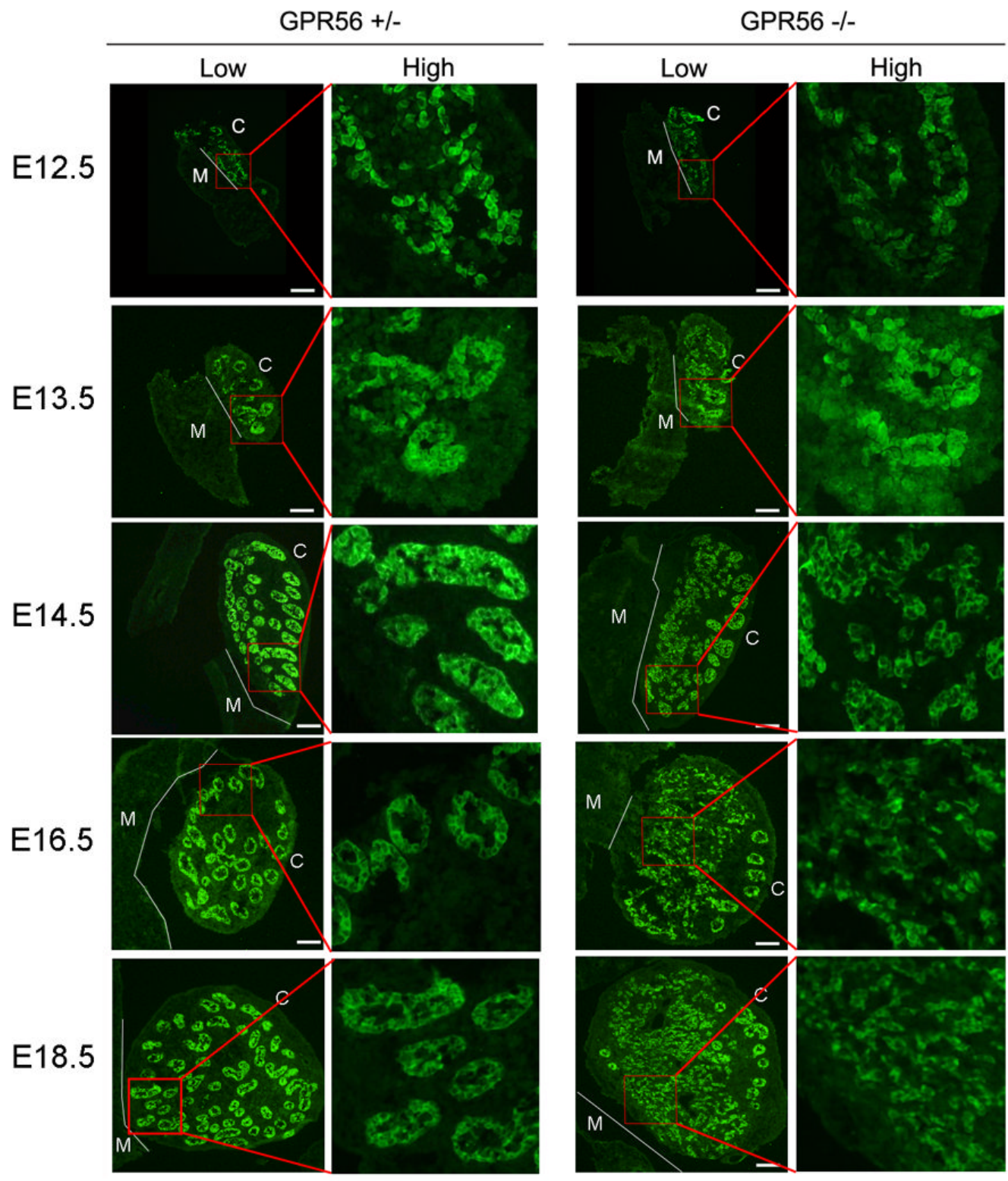

Figure 4. Disruption of testis cord development is polarized in $\mathrm{Gpr}^{56^{-1-}}$ embryos Genital ridges from $G p r 56^{+/-}$and $G p r 56^{-/-}$embryos $(\mathrm{n}=3$ for each genotype and stage) were stained with the anti-AMH antibody to visualize Sertoli cells during testis cord development. Whole genital ridges are shown on the left in low magnification, with an area close to the mesonephros (red box) shown in high magnification on the right. The boundaries between mesonephros and gonads are outlined by thin white lines. M: mesonephric side; C: coelomic side. Scale bar: $20 \mu \mathrm{m}$. The images reveal that testis cord development in $G p r 56^{-/-}$embryos is comparable to wild-type embryos at E12.5 and E13.5. However, at E14.5, E16.5, and E18.5, disruption in the formation of the testis cords on the mesonephric side (M) of Gpr56 $6^{-1-}$ embryos is evident. In contrast, the cords on the coelomic side $(\mathrm{C})$ remain intact. 


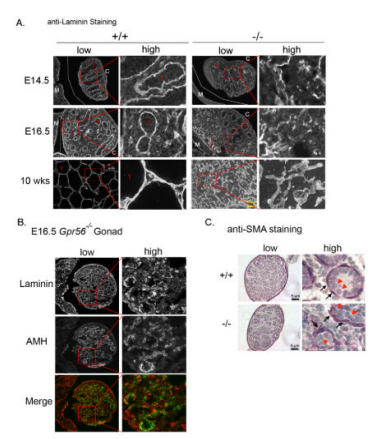

Figure 5. Basement membrane is not properly formed in $\mathrm{Gpr}^{56^{-/-}}$gonads A. $G p r 56^{+/-}$and $G p r 56^{-1-}$ embryonic gonads and adult testes $(\mathrm{n}=4$ for each stage and genotype) were stained with the anti-laminin 1 antibody. Images of low magnifications are shown on the left, with selected areas (red boxs) shown in high magnifications on the right. Laminin lines the testis cords (T) in $G p r 56^{+/-}$gonads and testes, but its localization is disrupted within the poorly organized regions of the $G p r 56^{-1-}$ testes. The boundaries between mesonephros and gonads are outlined by thin white lines. M: mesonephric side; C: coelomic side. Scale bar: $20 \mu \mathrm{m}$.

B. To examine the relationship between basement membrane and Sertoli cells in the absence of GPR56, E16.5 Gpr56 ${ }^{-/-}$gonads were co-stained with anti-laminin 1 antibody (red) and anti-AMH antibody (green). Images of low magnifications are shown on the left, with selected areas (red boxs) shown in high magnifications on the right. Sertoli cells appear to remain attached to laminin in the absence of GPR56.

C. The anti-SMA antibody was used to label the peritubular myoid (PM) cells in $G p r 56^{+/-}$ and $G p r 56^{-/-}$testes isolated from pups at P4 ( $\mathrm{n}=2$ for each genotype). Images of low magnifications are shown on the left, with selected areas (red boxes) shown in high magnifications on the right. In wild-type tubules, the SMA-positive cells are tightly associated with the Sertoli cells. This is also observed in the intact $G p r 56^{-/-}$tubules. In the disrupted area of $G p r 56^{-1-}$ testes (bottom panel), the PM cells continue to remain associated with the Sertoli cells. Black arrows: SMA-positive cells. Red arrowheads: Sertoli cells. 


\section{Table 1}

Fertility Tests For Gpr $56^{+/-}$and $G p r 56^{-/-}$Male Mice

\begin{tabular}{|c|c|c|}
\hline \multirow{2}{*}{} & \multicolumn{2}{|c|}{ Fertile/Total } \\
\cline { 2 - 3 } & Gpr56 $^{+/-}$ & Gpr56 $^{-/-}$ \\
\hline 7-14 weeks & $8 / 8(100 \%)$ & $4 / 10(40 \%)$ \\
\hline 16 weeks & $5 / 5(100 \%)$ & $2 / 8(17 \%)$ \\
\hline Total & $13 / 13(100 \%)$ & $6 / 18(33 \%)$ \\
\hline
\end{tabular}

Note: $\mathrm{Gpr} 56^{+/-}$and $\mathrm{Gpr} 56^{-/-}$male mice were bred with $\mathrm{Gpr}_{56^{+/-}}$females for 2.5 months (for 7 to 14 week-old mice) or 1.6 months (for 16 week-old mice). The males that produced offspring were considered fertile.

* the $\mathrm{Gpr}_{56^{+/-}}$mice included two of 7 weeks, two of 12 weeks, two of 13 weeks, and two of 14 weeks; the $\mathrm{Gpr} 56^{-/-}$mice included four of 13 weeks and six of 14 weeks. 